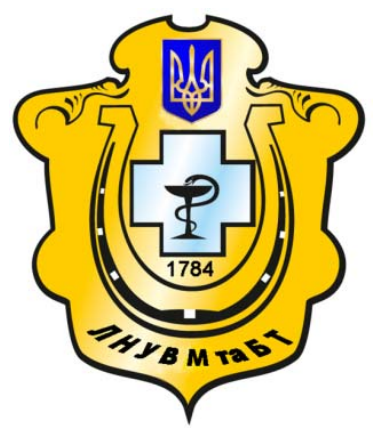

Науковий вісник Львівського національного університету ветеринарної медицини та біотехнологій імені С.3. Гжицького

Scientific Messenger of Lviv National University of Veterinary Medicine and Biotechnologies named after S.Z. Gzhytskyj

doi:10.15421/nvlvet7526

ISSN 2519-268X print

ISSN 2518-1327 online

$\underline{\text { http://nvlvet.com.ua/ }}$

УДК 637.51

\title{
Дослідження здатності до протеолізу м'ясних січених напівфабрикатів функціонального призначення
}

\author{
А.І. Українець ${ }^{1}$, В.М. Пасічний ${ }^{1}$, Д.А. Шведюк ${ }^{1}$, Ю.А. Мацук ${ }^{2}$ \\ pasww1@ukr.net, shvedyuk.d@ukr.net \\ ${ }^{1}$ Начіональний університет харчових технологій, \\ вул. Володимирська, 68, м. Київ, 01601, Украӥна; \\ ${ }^{2}$ Полтавський університет економіки і торгівлі, \\ вул. Коваля, 3, 36014, м. Полтава, Україна
}

Розроблено модельні рещептури м'ясних січених напівфабрикатів функиіонального призначення із застосуванням м'яса курчат бройлерів, білкової емульсії на основі білків свинячої шкурки та сухої молочної сироватки, клітковини пшеничної гідратованої, кониентрату зеленої маси подорожника та двох видів модифікованих жирів рослинного походження. Досліджено вплив внесення у рещептуру січених напівфабрикатів з м'яса птиці модифікованих жирів різного складу, рослинної сировини та клітковини гідратованої на здатність до протеолізу залежно від рещептурних співвідношень наведених компонентів. Здатність до протеолізу досліджена за допомогою ферментативного гідролізу під дію ферментів пепсину $i$ трипсину в системі іп vitro. При проведенні ферментативного гідролізу проаналізовано зразки, що містили в рецептурах білково-жсирову емульсію на основі білків свинячої шкурки та сухої молочної сироватки із застосуванням двох видів модифікованих жирів, що містять відповідно ріпакову та пальмову олї як основний складовий компонент. Як контрольну групу прийнято зразки, що відрізнялись відсутністю рослинної сировини (концентрату зеленої маси подорожника) у рецептурі, а також зразки із внесенням білкової емульсії без застосування жиру. Як дослідні зразки представлено зразки модельних січених м'ясних напівфабрикатів із вмістом білково-жсирової емульсії на основі білків свинячої шкурки та модифікованих жирів 22,5\% з однаковим рівнем внесення гідратованої пшеничної клітковини та концентрату зеленої маси подорожника (18 і 2\% відповідно). В ході проведених досліджень вимірювали рівень накопичення продуктів протеолізу у відібраних пробах гідролізату паралельно за двома методиками. Для фіксування гідролізу незамінних амінокислот використовували визначення вмісту тирозину за методом Лоурі. Для визначення загальної частки речовин пептидної та білкової природи у гідролізаті використовували біуретовий метод. За результатами досліджень встановлено, що у контрольних зразках на першій (пепсиновій) стадї протеолізу накопичується більше пептидних сполук, проте мало тирозину. У модельній групі зразків зафіксовано стабільну швидкість накопичення тирозину та перевищення кінцевого вмісту усіх пептидних сполук по завершенню повного циклу протеолізу.

Ключові слова: напівфабрикати, м'ясо птиці, клітковина, рослинна сировина, білково-жирова емульсія, протеоліз.

\section{Исследование способности к протеолизу мясных рубленных полуфабрикатов функционального назначения}

\author{
А.И. Украинец ${ }^{1}$, В.М. Пасичный ${ }^{1}$, Д.А. Шведюк ${ }^{1}$, Ю.А. Мацук ${ }^{2}$ \\ pasww1@ukr.net, shvedyuk.d@ukr.net \\ ${ }^{I}$ Нацииональный университет пищевых технологий, \\ ул. Владимирская, 68, г. Киев, 01601, Украина \\ ${ }^{2}$ Полтавский университет экономики и торговли, \\ ул. Коваля,3, 36014, Полтава, Украина
}

\section{Citation:}

Ukrainets, A., Pasichnyi, V., Shvedyuk, D., Matsuk, Y. (2017). Investigation of proteolysis ability of functional destinated minced half-finished meat products. Scientific Messenger LNUVMBT named after S.Z. Gzhytskyj, 19(75), 129-133. 
Разработаны модельные рецептуры мясных рубленых полуфабрикатов функционального назначения с применением мяса иуыплят бройлеров, белковой эмульсии на основе белков свиной шкурки и сухой молочной сыворотки, клетчатки пшеничной гидратированной, концентрата зеленой массы подорожника и двух видов модифицированных жиров растительного происхождения. Исследовано влияние внесения в рецептуры рубленых полуфабрикатов из мяса птицы модифицированных жиров различного состава, растительного сырья и клетчатки гидратированной на способность к протеолизу в зависимости от рецептурных соотношений приведенных компонентов. Способность к протеолизу исследована с помощью ферментативного гидролиза под действием ферментов пепсина и трипсина в системе іп vitro. При проведении ферментативного гидролиза проанализированы образцы, содержащче в рецептурах белково-жировую эмульсию на основе белков свиной икурки и сухой молочной сыворотки с применением двух видов модифицированных жиров, содержащих соответственно рапсовое и пальмовое масла в качестве основного составляющего компонента. В качестве контрольной группы принято образиы, которые отличались отсутствием растительного сырья (концентрата зеленой массы подорожника) в рецептуре, а также образиы с внесением белкового стабилизатора на основе белков свиной шкуры без применения жира. В качестве опьтнных образцов были выбраны образиы модельных рубленых мясных полуфабрикатов с содержанием белковожировой эмульсии на основе белков свиной шкурки и модифицированных жиров 22,5\% и одинаковым уровнем внесения гидратированной пшеничной клетчатки и концентрата зеленой массы подорожника (18 и 2\% соответственно). В ходе проведенных исследований измеряли уровень накопления продуктов протеолитиза в отобранных пробах гидролизата параллельно по двум методикам. Для фиксирования гидролиза незаменимых аминокислот использовали определение содержания тирозина методом Лоури. Для определения общуей доли веществ пептидной и белковой природы в гидролизате, использовали биуретовый метод. В результате исследований установлено, что в контрольных образцах на первой (пепсиновой) стадии протеолиза накапливается больше пептидных соединений, однако мало тирозина, тогда. В модельной группе образиов зафиксировано стабильную скорость накопления тирозина и превышение конечного содержания всех пептидных соединений по завершению полного ичикла протеолиза.

Ключевье слова: полуфабрикаты, мясо птицы, клетчатка, растительное сырье, белково-жировая эмульсия, протеолиз.

\title{
Investigation of proteolysis ability of functional destinated minced half-finished meat products
}

\author{
A. Ukrainets ${ }^{1}$, V. Pasichnyi ${ }^{1}$, D. Shvedyuk ${ }^{1}$, Y. Matsuk $^{2}$ \\ pasww1@ukr.net, shvedyuk.d@ukr.net \\ ${ }^{1}$ National University of Food Technologies, \\ Volodymyrska Str., 68, Kyiv, 01601, Ukraine; \\ ${ }^{2}$ Poltava University of economics and trade, \\ Kovala Str., 3, 36014, Poltava, Ukraine
}

The model recipes for minced half-finished meat products with the use of broiler chicken meat, protein emulsion based on porcine skins and dry whey, wheat hydrated fiber, plantain green mass concentrate and two kinds of modified vegetable fats are developed. The effect of various composition modified fats adding, vegetable raw materials and hydrated fiber on the ability to proteolysis depending on the prescription relationships of these components was studied in the recipes of minced half-finished meat products from poultry meat. The ability to proteolysis was studied by enzymatic hydrolysis under the action of enzymes pepsin and trypsin in an in vitro system. By enzymatic hydrolysis performing samples containing protein-fat emulsion based on proteins of porcine skin and dry whey in the formulations with two kinds of modified fats containing respectively rapeseed and palm oil as the main constituent of the component were analyzed in the formulations. As a control group, were taken samples, that differed in the absence of plant material (green plantain concentrate) in the formulation, as well as samples with the introduction of a protein emulsion without the use of fat. Samples of model minced half-finished meat products with a protein-fat emulsion based on porcine skin proteins and modified fats of $22.5 \%$ and the same level of hydrated wheat fiber and green plantain concentrate (18\% and $2 \%$, respectively) were selected as prototypes. In the course of the studies, the level of accumulation of proteolytic decomposition products in the selected samples of the hydrolyzate was measured by two methods in parallel. To fix the hydrolysis of essential amino acids, the determination of the tyrosine content by the Lowry method was used, and to fix the total proportion of peptide and protein substances in the hydrolyzate, the biuret method was used. As a result of the studies, it was found that in the control samples the first (pepsin) stage of proteolysis accumulates more peptide compounds, but fewer tyrosine, whereas in the model group of samples a stable rate of tyrosine accumulation and exceeding the final content of all peptide compounds after the complete cycle of proteolysis is fixed.

Key words: semi-finished products, poultry meat, fiber, vegetable raw materials, protein-fat emulsion, proteolysis.

\section{Вступ}

Згідно 3 останніми дослідженнями (Pasichnyi, 2002; Raksha-Sliusareva et al., 2013; Topchii et al., 2013; Pasichnyi et al., 2014; Pasichnyi et al., 2015), функціональні продукти на м'ясній основі та напівфабрикати зокрема є перспективним джерелом збагачення раціонів споживачів необхідними білковими речовинами, макро- та мікроелементами. Актуальним для таких продуктів є забезпечення їх біологічної цінності та біологічної ефективності. Здатність до протеолізу м'ясних напівфабрикатів та доступність їхнього білкового складу є важливим питанням, тому, що навіть при високій збалансованості складу незамінних амінокислот низька здатність до протеолізу білків може нівелювати якість білкового складу.

Meта $i$ завдання дослідження полягала у дослідженні здатності до протеолізу розроблених модельних січених напівфабрикатів на основі м’яса курчатбройлерів з різним рецептурним складом. 


\section{Матеріал і методи досліджень}

Дослідження проведено на установцігідролізаторі, що моделює процес перетравлювання в організмі людини за участю пепсину та трипсину (Pokrovskij and Ertanov, 1965). Протеоліз проведено у дві стадії по 3 години з проведенням на I стадії кислотного протеолізу з участю пепсину і на другій стадіїлужного протеолізу за участю трипсину.

Рецептури модельних напівфабрикатів наведено у табл. 1. Рецептура дослідних зразків (за варіантами 1, 2) включала в себе, окрім м'яса курчат-бройлерів, БЖЕ на основі модифікованих жирів (на основі ріпакової олії для зразка 1 і на основі пальмової олії для зразка 2), гідратовану пшеничну клітковину та концентрат зеленої маси подорожника. Напівфабрикати, за варіантами 3,4 і 5, містили у своєму складі м'ясо курчат бройлерів і гідратовану пшеничну клітковину, проте відрізнялись за вмістом БЖЕ, складом жиру та наявністю концентрату зеленої маси подорожника у рецептурі: 3 - напівфабрикат містив 22,5\% БЖЕ 3 жиром на основі ріпакової олії без внесення концентрату зеленої маси подорожника; 4 - напівфабрикат містив 22,5\% БЖЕ 3 жиром на основі пальмової олії без внесення концентрату зеленої маси подорожника; 5 - напівфабрикат містив у своєму складі білковий стабілізатор (22,5\%) на основі білка свинячої шкурки, сухої молочної сироватки та води у пропорції 4:1:15 без внесення модифікованого жиру та зеленої маси подорожника.

Рецептура модифікованого жиру включала рослинні олії у співвідношеннях: ріпакова - 63\%, пальмова - 7\%, пальмовий олеїн - 30\% (зразки 1-3). Рецептура другого виду жиру включала 70\% пальмової, 25\% кукурудзяної і 5\% лляної олії (зразки 4-6).

Таблиия 1

Рецептури дослідних зразків

\begin{tabular}{|l|c|c|c|c|c|}
\hline \multirow{2}{*}{ Сировина } & \multicolumn{3}{c|}{ Рецептури за варіантами } & \multicolumn{4}{c|}{} & 5 \\
\cline { 2 - 6 } & 1 & 2 & 3 & 4 & 42,5 \\
\hline М'ясо курчат-бройлерів, \% & 42,5 & 42,5 & 42,5 & 42,5 & 6,2 \\
\hline Клітковина, \% & 5,6 & 5,6 & 6,2 & 6,2 & 6,2 \\
\hline Вода, \% & 12,4 & 12,4 & 13,8 & 13,8 & 13,8 \\
\hline Концентрат зеленої маси подорожника, \% & 2,0 & 2,0 & - & - & - \\
\hline Сало, \% & 10,0 & 10,0 & 10,0 & 10,0 & 10,0 \\
\hline Емульсія, \%, з яких & 22,5 & 22,5 & 22,5 & 22,5 & 22,5 \\
\hline Білок свинячої шкурки, \% & 3,6 & 3,6 & 3,6 & 3,6 & 4,5 \\
\hline Модифікований жир на основі ріпакової олії, \% & 4,5 & - & 4,5 & - & - \\
\hline Модифікований жир на основі пальмової олії, \% & - & 4,5 & - & 4,5 & - \\
\hline Суха молочна сироватка, \% & 0,9 & 0,9 & 0,9 & 0,9 & 1,1 \\
\hline Вода, \% & 13,5 & 13,5 & 13,5 & 13,5 & 16,9 \\
\hline Панірувальні сухарі, \% & 5,0 & 5,0 & 5,0 & 5,0 & 5,0 \\
\hline
\end{tabular}

\section{Результати та обговорення}

В ході досліджень встановлено, що на першій стадії ферментативного гідролізу загальне накопичення пептидних сполук, що фіксувалось за біуретовим методом, у групі зразків за рецептурами 3-5 відбувається швидше, ніж у дослідній. Проте вміст тирозину у зразках за рецептурами 1 і 2 на першій стадії гідро- лізу (пепсинолізі) значно переважає зразки за рецептурами 3-5 і найкращим за цим показником є зразок 1. У другій стадії гідролізу зафіксовано менш помітні зміни у швидкості накопичення тирозину, але значне перевищення вмісту пептидних сполук у гідролізаті зразків 1 і 2. По закінченні протеолізу більше накопичення пептидних сполук зафіксовано у зразку 2, а тирозину - у зразку 1.

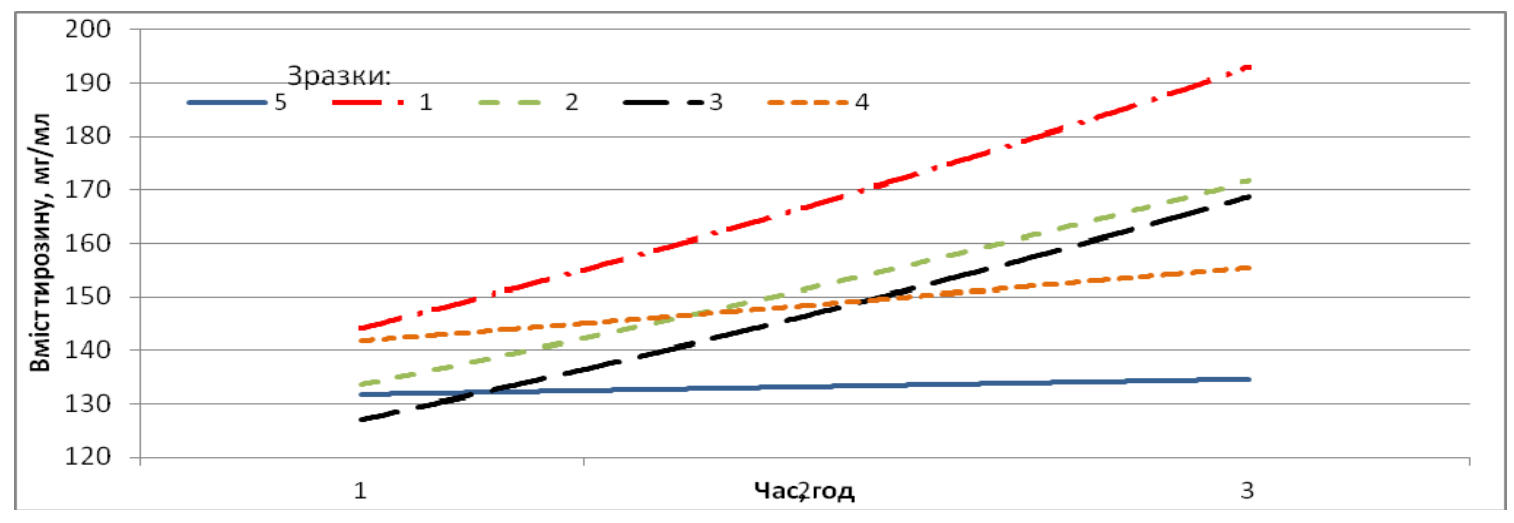

Рис. 1. Накопичення тирозину під час першої фази протеолізу 


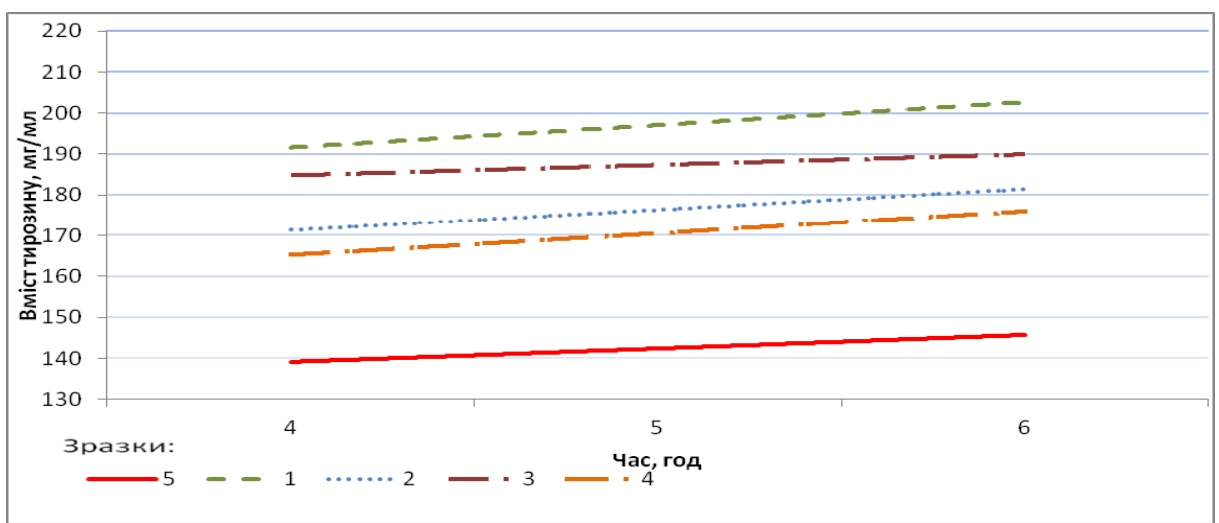

Рис. 2. Накопичення тирозину під час другої фази протеолізу

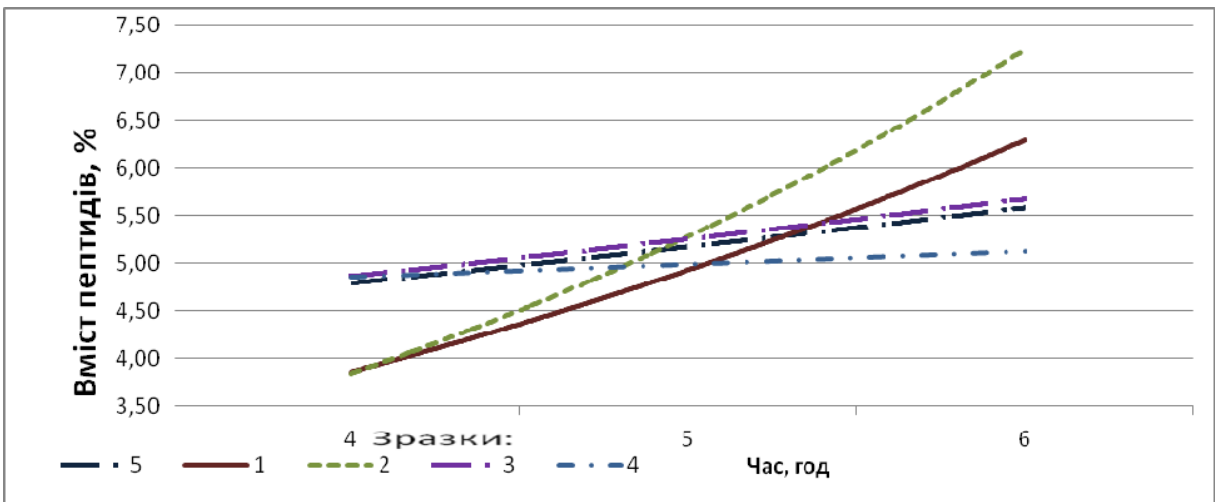

Рис. 3. Накопичення пептидів у гідролізаті на першій стадії протеолізу

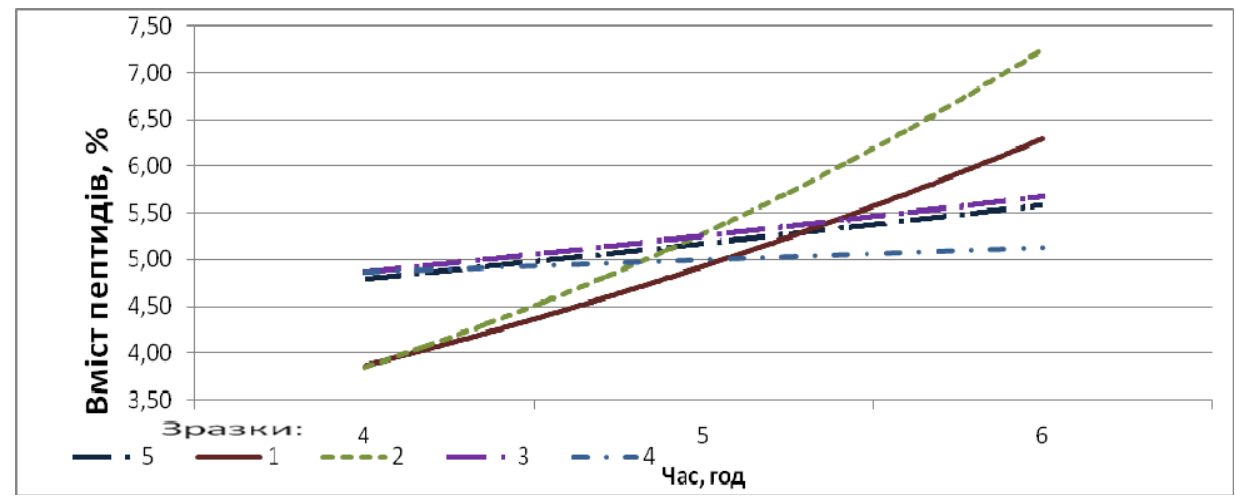

Рис. 4. Накопичення пептидів у гідролізаті на другій стадії протеолізу

\section{Висновки}

Представлена кінетика протеолізу білків напівфабрикатів підтвердила більш високий рівень біологічної цінності напівфабрикатів з використанням зеленої маси подорожника. Внесення сполучнотканинних білків до складу рецептур напівфабрикатів погіршуе їх здатність до протеолізу за відсутності ефекту комбінування тваринних та рослинних білків.

Таким чином, доведено позитивний вплив комбінування тваринних та рослинних білків для підвищення біологічної цінності м'ясних січених напівфабрикатів.

Перспективи подальших досліджень. Подальшими дослідженнями передбачено визначення споживчих показників розроблених напівфабрикатів в термінах їx зберігання.

\section{Бібліографічні посилання}

Pasichnyi, V.M. (2002). Ranhove otsiniuvannia kombinovanykh m'iasoproduktiv. Naukovi pratsi NUKhT. 11, 77-80 (in Ukrainian).

Raksha-Sliusareva, O., Krul, V., Popova, N. (2013). Kharchova tsinnist miasnykh napivfabrykativ iz vykorystanniam diietychnoi dobavky z ripaka. Tovary i rynky. 1, 110-117 (in Ukrainian).

Topchii, O.A., Kyshenko, I.I., Kotliar, Ye.O. (2013). Vykorystannia roslynnykh olii u retsepturakh miasnykh pashtetiv. Naukovyi visnyk Lvivskoho 
natsionalnoho universytetu veterynarnoi medytsyny ta biotekhnolohii im. Gzhytskoho. 15, 1(3), 169-173 (in Ukrainian).

Pokrovskij, A.A., Ertanov, I.D. (1965). Atakuemost' belkov pishhevyh produktov proteoliticheskimi fermentami in vitro. Voprosy pitanija. 3, 33-44 (in Russian).

Jiménez-Colmenero, F, Carballo, J, Cofrades, S. (2001). Healthier meat and meat products: their role as functional foods. Meat Sci. 59(1), 5-13, doi: 10.1111/j.1365-2621.2005.tb07110.x

Pasichnyi, V.M., Simakhina, H.O., Heredchuk, A.M., Zadorozhnii, V.V. (2014). Miasomistki napivfabrykaty kulinarni z miasa ptytsi pidvyshchenoi kharchovoi tsinnosti. Naukovyi visnyk Lvivskoho natsionalnoho universytetu veterynarnoi medytsyny ta biotekhnolohii im. Gzhytskoho. 16, 2(4), 149-155 (in Ukrainian).

Pasichnyi, V.M., Heredchuk, A.M., Moroz, O.O., Yastreba, Yu.A. (2015). Doslidzhennia faktoriv prolonhatsii terminiv zberihannia miasnykh i miasomistkykh produktiv. Naukovi pratsi Natsionalnoho universytetu kharchovykh tekhnolohii. 21(4), 224-230 (in Ukrainian).

Стаття надійшла до редакиії 5.03.2017 